\title{
DISCOVERING SELF STRENGTH, BUILDING ENTREPRENEURIAL SPIRIT AMONG SENIOR HIGH SCHOOL STUDENTS AT KEMBANGAN SUBDISTRICT WEST JAKARTA (Preparing Millennials to Excel and Innovate)
}

\author{
${ }^{1}$ Edy SUROSO, Nurul HIDAYAH ${ }^{2}$, and Anees Janee ALI ${ }^{3}$ \\ ${ }^{1,2}$ Universitas Mercu Buana Jakarta, Indonesia \\ ${ }^{3}$ Universiti Sains Malaysia \\ edy.suroso@mercubuana.ac.id ; nurul.hidayah@mercubuana.ac.id ; aneesali@usm.com
}

\begin{abstract}
God created humankind certainly with purposes: as a noble being and caliph on earth with given uniqueness of potential and strength. Humankind is gifted with brain to think, the act of thinking is basically the act of asking, the act of asking is searching for the answers, and searching for the answers is the root of looking for the truth. If we explore and discover these unique potentials of humankind, then we will know the tasks that we need to carry out in our lives to the best of our capabilities. The best of humankind is the ones that benefits others. This Community Service Activity (PKM) carries the main theme of "Preparing Millennials to Excel and Innovate" with a subtheme: "Discovering Self Strength, Building Entrepreneurial Spirit among Senior High School Students" at Kembangan Subdistrict West Jakarta. This PKM is a suitable and important programme for the senior high school students to prepare themselves for graduation, especially during this Covid-19 pandemic. The students are provided with new knowledge, mission- visions, as well as mentoring in finding their potentials and strengths, finding paths and ways to success, and understanding about their talents, knowledge, and skills, which will lead to potentials and strengths. It is hope that the students can optimize their strengths and prepare themselves with future challenges:whether to further their studies to higher level, or working with organizations or to become entrepreneurs, or another option is to be part-time students in college while working or being entrepreneurs. All potentials including the entrepreneurial spirit based on creativity need to be grown and nourish among students from now on. "Meeting \& Greeting - Sharing \& Knowing- Networking" is essential to be prepared among students. Other knowledge in entrepreneurship also needs to be acknowledged and learnt by students, such as accounting and financial governance to help millennial entrepreneurs in managing financial information.
\end{abstract}

Keywords: Community Service, Millennials, Self- Potential, Talent, Entrepreneurship, Accounting

\section{BACKGROUND}

According to Law No.20 of 2003 on The National Education System, Article 3, the purpose of National Education is to develop the potential of learners to become humankind who believe and fear God Almighty, noble, healthy, knowledgeable, capable, creative, independent, and become democratic and responsible Indonesian citizens. Education is a conscious and planned effort to realize the atmosphere of learning and learning process so that learners actively develop their potential to have religious-spiritual power, self-control, personality, intelligence, noble morals, as well as the necessary skills themselves, society, nation, and country. The word planned means education is a system. Rules, objectives, and content, as well as clear and directional flow, are required to develop the potential of learners.

In Government Regulation No.:17 of 2010 on The Management and Implementation of Education states that secondary education is the level of education on the path of formal education which is a continuation of primary education, in the form of Senior High School, Madrasah Aliyah, Vocational High School, and Madrasah Aliyah

Vocational or other similar forms. Meanwhile, Dwi Siswoyo (2007:21), said that education is a lifelong process. The educational process is not short- To shape and develop human potential, awareness, motivation, material delivery, and guidance are required, as well as continuous evaluation until the desired potential has been embedded in the learners.
According to Ir. Rama Royani (better known as Abah Rama) Inventor of Talent Mapping Indonesia) in his book: Talents Mapping: Inspiration For a More Fun and Meaningful Life, (Tosca, -2016), then in the book Talents Dynamics: Practical Steps to Explore The Character of Your Performance (Tosca-2017), said that man wascreated by God very perfectly, God has bestowed uniqueness (talent) to every human being and provide a wide space so that the potential can be optimal. Strength as a result of the process of managing talent. If a talent pool is named as a potential strength, then strength is something that makes a person productive and engrossed in what he or she is doing. It is believed that each of these selves has strengths and limitations. So working together by benefiting various fields becomes the main thing.

This devotional activity was held on Friday, January 29, 2021, through webinar- zoom taking the big theme "Preparing Millennials to Excel and Innovate" with Sub Theme: Discovering Self Strength, Building Entrepreneurial Spirit among Senior High School Students at Kembangan Subdistrict West Jakarta, in collaboration with partners from SMA Negeri 101 Jakarta, MAN 10 Jakarta, and SMK - YMIK.

The theme of the discussion is based on the understanding that man was created by God certainly with purposes: as a noble being and caliph on earth with given uniqueness of potential and strength. Humankind is gifted with brain to think, the act of thinking is basically the act of asking, the act of asking is searching for the answers, and searching for the answers is the root of looking for the 
truth. If we explore and discover these unique potentials of humankind, then we will know the tasks that we need to carry out in our lives to the best of our capabilities. The best of humankind is the ones that benefits others. Indeed, in every human being contained a unique advantage/ potential/power that is ready to be explored and found to be then empowered and utilized in building superior performance.

Finding yourself does not mean just discovering potential strength, but it is as important as to find own's limitations. Every creature is created with power and limitations. With the spirit of the process of finding "The Strength of Himself" (Your Own Strengths) and trying to prepare for challenges in improving his capacity and ability to provide added value for himself, his family, a $\mathrm{n} \mathrm{d}$ the surrounding community. Especially in the current situation, where since March 2020 until now with the Covid-19 pandemic, still shows an increasing trend, and there is no certainty when this pandemic will end. This pandemic will have a big impact on parents and the community in general and will have an impact on students as well, thus adding to the existing burden and problems.

\section{SOLUTIONS AND TARGETS}

Senior High School students in their age are often involved in the process of self- discovery. There are cases that a few of them experience an identity crisis. Some of them are students who are sitting in class XII who are soon facing the final exams of school before graduation. In the situation of the Covid-19 pandemic, it has a big impact for both parents and students. Both parents and students are full of anxiety of what is happening next after graduation. Whether to continue studying at a college, or looking for jobs, and or to become entrepreneurs. Some are thinking of studying part time while working. All these are a matter of choice.

Deputy for Coordination of Education and Religion of the Coordinating Ministry for Human Development and Culture, Agus Sartono said that there are 1.8 million senior high school graduates who are forced to work and cannot continue to higher education. Senior High school graduates must find work with a senior high school degree or equivalent. They have to compete with \pm 1.3 million college graduates with both bachelor and diploma degrees in finding work each year. While employment opportunities for senior high school graduates are narrowing as the times and the technological and industrial revolutions, where employment, especially those that open opportunities for secondary education graduates, is narrowing. If there is no concrete and significant effort to address this, then job seekers and employment opportunities will not be balanced. The narrowing of employment in many sectors will continue to occur along with economic growth. Agus explained that there are at least 3.7 million secondary education graduates every year. Of these, only 1.9 million continued their education to higher education. Then the other 1.8 million have to think of what to do next. This does not include the open unemployment rate. Nor has it counted the population who drop out of school. (Source :CNN Indonesia/Djonet Sugiarto= News : 11-03-2020).

According to the Central Bureau of Statistics (BPS): As of February 2019, there is at least 6,816,840 open unemployment in Indonesia. The breakdown of the amount varies based on the highest education completed. The highest number of open unemployed are high school graduates or equivalent, which is $1,680,794$ people. Followed by senior high school graduates and equivalent as many as 1,381,964 people, junior high school graduates, and the equivalent of 1,219,767 people. Then elementary school graduates and equivalent as many as 954,010 people, university graduates as many as 839,019 people. Those have not finished elementary school as many as 435,655 people, diploma graduates as many as 269,976 people, and the group that has never been to any school as many as 36,655 people. BPS as of February 2020 announced the national open unemployment rate (TPT) is dominated by graduates of Vocational High Schools (SMK). Meanwhile, the number of TPT is as many as 6.88 million people. Furthermore, the Head of BPS, Suhariyanto said the number of vocational school graduates who became unemployed is as much as $8.49 \%$ of the unemployment rate of 6.88 million unemployed people. "TPT SMK is still the highest among other education levels, namely $8.49 \%$ ". (Source: finance.detik. com, Tuesday: 5/5/2020).

To help and find solutions to the many problems that are being faced by students, this devotional activity, that is this PKM was carried out. All potentials of the senior high school students need to be excavated and realized. These potentilas then need to be grown from now on through the discovering of self strength. It is expected that the students can recognize and optimize their own strengths. The students need to realise about future challenges and prepared with future challenges they may face. The students need to think wisely whether to further study, or work with companies or become entrepreneurs, or maybe to continue studying while working.

Through this PKM activity, students are able to measure in which position they are in the community, especially for those who are expecting school graduation. Furthermore, educational factors (enculturation) are also important to develop, hone themselves, and sharpen their potential (strength), to strengthen their characteristics and competitiveness of performance. Self-potential is the advantages/abilities that are inherent in a person, in addition to being reviewed and felt by the individual concerned or others around him, especially close people or some experts such as psychologists, psychiatrists, guidance experts, and others.

Developing self-potential is a way to improve one's standard of living, whichis usually done through the process of learning and teaching (learned action). 
Discovering yourself is not only finding potential strength but also just as important to realise own limitations (potential weaknesses). Every human being is created with power and limitations. With a spirit that can be said as the process of finding own's strength and trying to prepare for limitations by improving his capacity and ability to grow entrepreneurial spirit.

After participating in this PKM activity, here are the external achievement of the senior high school students who participated in this PKM program:

\begin{tabular}{|c|c|c|c|}
\hline No & Problems & Solutions & External \\
\hline 1 & $\begin{array}{l}\text { Various Student } \\
\text { Problems }\end{array}$ & $\begin{array}{l}\text { Generating Self- } \\
\text { Motivation of High } \\
\text { School Students }\end{array}$ & $\begin{array}{l}\text { Discovering } \\
\text { his unique self } \\
\text { potential/strength } \\
\text { in himself }\end{array}$ \\
\hline 2 & $\begin{array}{l}\text { The future } \\
\text { after Senior } \\
\text { High School } \\
\text { Graduation }\end{array}$ & $\begin{array}{l}\text { Provide assistance } \\
\text { to stay optimistic } \\
\text { \& dare to make } \\
\text { choices }\end{array}$ & $\begin{array}{l}\text { Improving } \\
\text { understanding - } \\
\text { Consequences of } \\
\text { Choice: College- } \\
\text { Tuition fee, } \\
\text { working or } \\
\text { becoming } \\
\text { entrepreneurs. }\end{array}$ \\
\hline 3 & $\begin{array}{l}\text { Economic } \\
\text { Limitations }\end{array}$ & $\begin{array}{l}\text { Provide supplies if } \\
\text { the choice isworking } \\
\text { or becoming } \\
\text { entrepreneur }\end{array}$ & $\begin{array}{l}\text { Choice of } \\
\text { working or } \\
\text { becoming } \\
\text { entrepreneurs } \\
\text { based on } \\
\text { the needs of the } \\
\text { market. }\end{array}$ \\
\hline 4 & $\begin{array}{l}\text { Finding } \\
\text { Alternative } \\
\text { Solutions }\end{array}$ & $\begin{array}{l}\text { Provide a variety } \\
\text { of alternatives / } \\
\text { solutions to excel } \\
\text { and succeed intheir } \\
\text { chosen life }\end{array}$ & $\begin{array}{l}\text { Building } \\
\text { entrepreneurial } \\
\text { spirit, working } \\
\text { Or become } \\
\text { entrepreneurs } \\
\text { while studying, } \\
\text { excelling and } \\
\text { succeeding in } \\
\text { their fields. }\end{array}$ \\
\hline 5 & $\begin{array}{l}\text { Provision of } \\
\text { Knowledge }\end{array}$ & $\begin{array}{l}\text { Provide the } \\
\text { knowledge of } \\
\text { accounting \& } \\
\text { financial } \\
\text { governance }\end{array}$ & $\begin{array}{l}\text { Understand the } \\
\text { important role } \\
\text { of accounting } \\
\text { as a tool in the } \\
\text { management } \\
\text { of financial } \\
\text { governance. }\end{array}$ \\
\hline
\end{tabular}

After participating in this PKM programme, the students are expected to benefit from it and be able to: Grow self-motivation, build awareness and explore various unique potentials and ultimately be able to discover their potential/strength. Optimistic in making choices through a variety of careful considerations and at the same time able to provide a variety of alternative solutions and provisions for the future.

\section{METHOD}

The activity of this PKM was implemented by conducting online webinars by selecting senior high school students from MAN, VOCATIONAL \& Equivalent. This PKM was conducted in collaboration with several teams from Group 2 (which consist of 7 groups), Community Service from Mercu Buana University (UMB) Jakarta with its Partners from 101 Senior High School Jakarta, MAN 10 Jakarta, SMK YMIK. The activity began with the opening ceremony, singing the song of Indonesia Raya, Speech from the UMB Campus, followed by speeches from several School Leaders/ Representatives who participated in this PKM programme. Submission of materials, through the division of room meetings respectively, such as Room $101=$ For webinar participants students and students from 101 Senior High School Jakarta which was also attended by teaching staff, teachers and leaders of 101 Senior High School Jakarta school concerning the webinar theme: "Discover the Strength of Self, To Build entrepreneurial spirit in senior high school and equality in Kembangan District". By providing a variety of understanding, implementation of strategies, as well as motivation to grow the entrepreneurial spirit at early stage. By giving a talk and understanding of i.) Cultivating Self Motivation ii) Finding own strength, iii) Foster entrepreneurial spirit and iv) Business Governance through the knowledge in Accounting. At the end of the seminar, discussions and questions, and simulations were conducted. Finally, then seminar participants returned to the "Main Room" for the closing ceremony of the PKM webinar.

\section{RESULTS AND DISCUSSIONS}

This PKM programme was attended by more than 100 participants consisting of senior high school students accompanied by the Principals /Vice Principals and teachers from the participated schools. Education role mentoring material delivery activities find strength (potential) self, packed in the spirit of building an entrepreneurial spirit as an effort to realize millennials who excel and succeed according to their fields, potentials, and competencies, by focusing on the discussion:

Foster Self Motivation. Understanding various things related to motivation that becomes a driving factor so that students can explore their strength to support their ideas and missions so that they can succeed in the future. Such as Determination of Intention, Virtue of Science, Understanding Success, Basic Capital of Success, Discovering Process, Motivating Self effectively, Effectively and Efficiently in carrying out all endeavors and efforts by its competence. Also given a briefing on the challenges that will be faced and how to solve the problem.

Finding Strengths \& Limitations of Own Self. Our parents always advice us to be ourselves. If only we could know who we are and what we are created for, God willing, we would find a way and the way of success. Indeed, every designer/creator has a purpose when designing or creating something. We can know the purpose and purpose of the designer/creator by looking at the results of the design or product of his creation. Humans are also created with different designs or features. God certainly has a certain purpose and purpose by creating people with different forms and forms. As long as there are people who live 
on the face of the earth. Humans are unique, second to none, even though billions of humans have been created in the world, none of them are the same even twins. So unique that each person is a Very Special Limited Edition. Uniqueness, different from one human to another? The answer is nature or personality. personality referred to here is a useful personality or productive personality. This productive personality is hereinafter referred to as TALENT. Talent in a broad sense is self-potential. The potential that every human being has is God's most precious gift, but often we forget it Every human being has potentials both in the form of advantages and limitations. But generally, man is confined to overcome the limitations on him rather than develop the potential of his power. The main thing to remember is that every human being must have an advantage, a unique power that is different from the others and everything must begin with selfdiscovery. There are several ways to discover the potential of our talents and strengths, including i) Talents Mapping Assessment, among others by exploring the productive nature (talent) of a person, interpreting the power related to roles through dominant talents, ii). Assessment of Personal Strength Statement (PSS), among others by exploring recognition of productive activities, which is an overview of ability/competence and interest in activities.

In addition to being useful to recognize personal potential, the above assessment can be used as a tool for some interests, either for personal, group, organization, or company. Some benefits for individuals such as for career selection, education majors or professions; or organization or company such as for recruitmentor selection, counseling, placement of positions or promotions, formation of working groups (team building), development, training, career planning, and performance management.

Furthermore, the PKM participants were also given an understanding of the spirit of Entrepreneurship by combining elements of "Good Business Governance", from several fields of knowledge, such as marketing, corporate management and accounting. The flow chart of the discussion material, as follows:

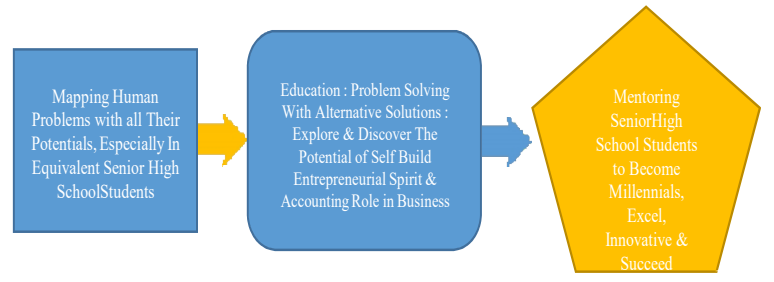

\section{Flowchart Explanation.}

Phase 1: Mapping the problem that a man is a unique creature, reasoned, thinking, which has a variety of potentials in both strength and limitations. Especially for senior high school students who are in the process of finding their identity with various challenges, in order to determine their future direction.

Phase 2: Problem solving education by providing various alternative solutions by providing understanding that: The main foundation in human life is Faith \& Taqwa to God Almighty. Man with a variety of unique potentials that is a provision given by God to every human being, certainly has a noble task and role in accordance with the role he held. To know all these unique potentials, each self is given the task to endeavor to explore and find the potential (strength) of himself, while it is expected to build the spirit of entrepreneurship and learn various knowledge that can support the business, such as the role of accountant that can help in good and successful business governance.

Phase 3: Mentoring stage for students to become Millennials, Superior, Innovative and Successful, among others by providing understanding, that:

i) After being able to recognize the potential of self, then develop it through education, either formal or nonformal, then apply it in the chosen field of work, then the important thing to note every human being is the cultural background in which he was raised. Similarly, the teachings of religion as a way of life.

ii) Provide motivation \& determination/passion for students to succeed through efforts to find self-potential and foster an independent soul and entrepreneurship.

iii) Entrepreneurship is one of the support of economic growth in Indonesia. Its role is so central to the welfare of the Indonesian people, carrying the mission that the young generation of Indonesia has skills and is able to be independent with an entrepreneurial spirit.

iv) Provide an understanding of the important role of Accounting in business/ entrepreneurship.

The implementation of this devotional activity was published through several online media such as: Makobar. com based in Medan which aired on February 19, 2021 with a link https://makobar.com/universitas-mercu-buanaberikan-materi- entrepreneur-kepada-siswa- sma-smk-lewatwebinar/.

\section{CONCLUSION}

The implementation of community service programme conducted by the campus of Mercu Buana University Jakarta through webinar seminars online with its partners from 101 Senior High School Jakarta, MAN 10 Jakarta, SMK YMIK was conducted successfully and smoothly. This programme is the right step especially in the situation of the Covid.9 pandemic. Through team PKM-UMB Jakarta from Group 2 with partners from 101 Senior High School Jakarta, through Room: 101, Vice Principal of 101 Senior High School Jakarta Mr. Suyadi, Mpd, expects that this kind of programme to be continued and improved, so that the relationship between Mercu Buana University Jakarta and 101 Senior High School Jakarta can be the relationship cab be nourished, in order to transfer knowledge to students to prepare themselves to become better and innovative and successful millennial generation in the future.

It is expected that on other occasions, cooperation can be re-implemented with equivalent senior high school 
partners such as 101 Senior High School, MAN 10 Jakarta, and SMK YMIK, with different themes or topics, so that their knowledge will increase. It is expected that on the next PKM programme, in addition to being able to partner with other senior high schools in Kembangan Subdistrict, West Jakarta, but also can partner with senior high schools in the other sub-districts in the DKI Jakarta area.

\section{REFERENCE}

Bps.go.id/pressrelease/2020/05/05/1672/ februari-2020

CNN Indonesia/Djonet Sugiarto= Berita : 11 Maret 2020).

Finance.detik.com (Sumber BPS, 5 Mei 2020), Data Pengangguran Tingkat Pengangguran Terbuka (TPT)

Finance.detik.com/berita-ekonomi-bisnis/d5003020/68-juta-orang-indonesia-

Kotler, Philip, 2012, Manajemen Pemasaran, Salemba Empat, Jakarta

Menggali, Menemukan \& Mengembangkan Kekuatan; Abah Rama Limawira Wisesa 2007

Optimalkan Potensi Anda!. Seri ManajemenPraktis Drs J. Tanzil \& Rekan ; 2005

Publikasi.data.kemdikbud.go.id >(2020). Gambaran Umum SMA \& SMK Seluruh Indonesia.

Porter, Michael E, 2002, Strategi Bersaing, penerbit Erlangga, Jakarta
Pusat Pengabdian pada Masyarakat, Universitas Mercu Buana, Jakarta. http://ppm.mercubuana. ac.id/?page_id=5.

Referensi.data.kemdikbud.go.id/index11.php (2020)

Rencana Pengembangan Ekonomi Kreatif 2009 2015, 2008, Departemen Perindustrian dan Perdagangan

Richard Barringer, dkk (2004) "The Creative Economi in Maine Riduwan, 2010,

Riduwan, 2010, Metode dan Teknik Menyusun Tesis, Penerbit Alfabeta

Robbin, Stephen P, 2010, Perilaku Organisasi. Jakarta: PT INDEKS Kelompok Gramedia

Spencer and Spencer, 2003, p.24, Competence at Work: Model for SuperiorPerformance, John Wiley \&Sons, Inc, New York

Suryana, 2009, Analisis Rantai Nilai (Value Chain) pada Industri Kreatif di Pedesaan.

The IRS Handbook on Competencies : Law and Practise, 2001 Publikasi-Publikasi: BPS,2013.

Telents Dynamics : Abah Rama Royani - Endro P.ALangkah Praktis Mengeksplorasi Karakter Kinerja Anda, Tosca 2017

Talents Mapping : Abah Rama Royani, Inspirasi Untuk Hidup Lebih Asyik dan Bermakna, Tosca,2016 